\title{
PERLINDUNGAN HUKUM DEBITOR PADA PINJAMAN KREDIT DALAM MENINGKATKAN TARAF HIDUP ${ }^{1}$
}

\author{
Robiatul Adawiyah* dan A. Tulus Sartono \\ Program Studi Magister Ilmu Hukum \\ Fakultas Hukum Universitas Diponegoro \\ Jl. Imam Bardjo Pleburan, Kota Semarang, 50241 \\ robiatul.adawiyah.alhabsyi@gmail.com
}

\begin{abstract}
Credit loans allow for non-performing loans culminating collateral sales that implications for community living standards (debtors) so it is very important to study debtor legal protection on credit loans in increasing living standards. The purpose are to uncover facts and analyze it. The research method is socio-legal. A credit agreement which is standard agreement allows for nonperforming loans, effecting in collateral sales. Facts show increase in collateral sales with Article 6 on Law of Mortgage as favourite as a basis for sales. This disturb the community justice sense as evidenced by many lawsuits addressed to KPKNL and court disputes. The debtors legal protection on credit loans from beginning of agreement to collateral sale is very weak so that it impacts on the community living standard.
\end{abstract}

Keywords: Credit Loans; Debtors; Legal Protection; Living Standard

\begin{abstract}
Abstrak
Pinjaman kredit memungkinkan terjadi kredit bermasalah yang berujung pada penjualan agunan yang berimplikasi pada taraf hidup masyarakat (debitor) sehingga sangat penting mengkaji perlindungan hukum debitor pada pinjaman kredit dalam meningkatkan taraf hidup. Tujuan artikel ini adalah untuk mengungkap fakta dan menganalisis perlindungan hukum debitor pada pinjaman kredit dalam meningkatkan taraf hidup. Metode penelitiannya adalah penelitian sosiolegal. Perjanjian kredit yang merupakan perjanjian baku memungkinkan adanya kredit bermasalah sehingga dilakukan penjualan agunan. Fakta di lapangan menunjukkan peningkatan penjualan agunan dengan Pasal 6 UU HT sebagai primadona dasar penjualannya. Hal ini telah mengusik rasa keadilan masyarakat dibuktikan dengan banyaknya gugatan kepada KPKNL maupun sengketa pengadilan. Perlindungan hukum debitor terhadap pinjaman kredit sejak awal pembuatan perjanjian baku sampai dengan penjualan agunan sangatlah lemah sehingga berdampak pada taraf hidup masyarakat.
\end{abstract}

Kata Kunci: Pinjaman Kredit; Debitor; Perlindungan Hukum; Taraf Hidup

\footnotetext{
${ }^{1}$ Penelitian mandiri yang dilakukan penulis satu pada studinya di Program Magister Ilmu Hukum Fakultas Hukum Universitas Diponegoro, tahun 2020.
} 


\section{A. Pendahuluan}

Kebijakan pembangunan ekonomi di Indonesia merupakan sebagian dari pembangunan nasional sebagai upaya untuk mewujudkan tujuan nasional sebagaimana tercantum dalam alinea keempat Pembukaan Undang-Undang Dasar Negara Republik Indonesia Tahun 1945 (selanjutnya disingkat UUD NRI Tahun 1945), yaitu melindungi segenap bangsa Indonesia dan seluruh tumpah darah Indonesia dan untuk memajukan kesejahteraan umum, mencerdaskan kehidupan bangsa dan ikut melaksanakan ketertiban dunia yang berdasarkan perdamaian abadi, kemerdekaan, dan keadilan sosial (Rahmawati \& Cahyaningsih, 2016). Kegiatan pembangunan tersebut tentu membutuhkan penyediaan dana yang cukup besar, yang dapat diperoleh melalui kegiatan kredit yang dalam pemenuhannya dibantu lembaga perbankan (Watikno \& Imanullah, 2019). Pemberian kredit diikuti dengan suatu hubungan hukum dalam bentuk perjanjian berupa perjanjian kredit (Dianawati \& Purnawan, 2017).

Perjanjian kredit merupakan suatu perjanjian utang piutang antara bank selaku kreditor dan masyarakat selaku debitor yang ditekankan kepada kesepakatan para pihak berdasarkan pada kebebasan dalam membuat perikatan (Aryani \& Djajaputra, 2018). Namun, mengingat pemberian kredit juga mengandung risiko kegagalan pelunasan mengakibatkan terdapat kemungkinan kredit bermasalah, sehingga bank wajib untuk mengelola risiko tersebut dalam manajemen risiko (Suwandi, 2018). Jika kerugian bank akibat kredit bermasalah tidak dapat diselesaikan maka digolongkan dalam kredit hapus buku atau hapus tagih maka akan dapat mengurangi modal bank dan bank yang tidak memenuhi persyaratan modal minimum akan termasuk dalam bank bermasalah (Bahsan, 2012). Agar dapat mengurangi risiko tersebut diperlukan adanya lembaga jaminan sebagai sarana pengaman. Dana kredit yang disalurkan harus dilakukan secara hati-hati (prudent) (Purnamasari, 2014). Jaminan khusus yang diminta oleh bank dalam penyaluran kredit merupakan realisasi dari prinsip kehatihatian sebagaimana ditentukan UndangUndang Republik Indonesia 10 Tahun 1998 tentang Perubahan Atas Undang-Undang Nomor 7 Tahun 1992 tentang Perbankan (selanjutnya disingkat UU Perbankan). Jaminan kebendaan mempunyai posisi paling dominan dan dianggap strategis dalam penyaluran kredit bank dan yang paling banyak diminta oleh bank adalah berupa tanah karena secara ekonomis tanah mempunyai prospek yang menguntungkan (Prasojo \& Anand, 2018). Untuk kredit yang jaminannya berupa tanah maka dibebani hak tanggungan. Apabila terdapat wanprestasi maka jaminan tanah yang dibebani hak tanggungan tersebut dapat dieksekusi. Hal ini merupakan bentuk perlindungan kepada kreditor.

Lantas, bagaimana perlindungan hukum terhadap debitor yang dalam pinjaman kredit? Pihak dalam pinjaman kredit bukan hanya kreditor melainkan juga debitor yang justru lebih membutuhkan perlindungan hukum mengingat posisinya yang rentan atas kesewenang-wenangan bahkan sejak dibuatnya perjanjian kredit yang merupakan perjanjian baku atau standar. Debitor merupakan pihak yang membutuhkan uang, sedangkan kreditor adalah penyedia dana, sehingga perlindungan hukum debitor sangatlah rentan. Di samping itu, pinjaman kredit berisiko bermasalah memungkinkan untuk dilakukan eksekusi, sehingga debitor akan kehilangan tanahnya. Menurut Chigozie Nwagbara, masalah eksekusi tanah yang dibebani hak tanggungan di antaranya nilai jual yang rendah. Meskipun dalam pengadilan diputus kreditor tidak dapat menjual kepada dirinya sendiri, tapi fakta kreditor menjual kepada relasi ataupun mitra yang menempatkan tanggung jawab pada pemberi pinjaman untuk menunjukkan bahwa semuanya dilakukan dengan adil dan dia mengambil tindakan pencegahan yang wajar (Nwagbara, 2014). Bahkan kerap pemenang lelang masih memiliki hubungan kekeluargaan sehingga potensi ketidakadilan ini sangatlah memungkinkan. Dengan 
kondisi demikian, bagaimana meningkatkan taraf hidup masyarakat sebagaimana tujuan kebijakan pembangunan ekonomi bangsa Indonesia?

Beberapa penelitian terdahulu membahas mengenai perlindungan hukum bagi kreditor dalam perjanjian kredit atas debitor yang wanprestasi (Risa, 2019) (Anwar, 2014) (Walidani \& Adjie, 2018). Adapun peneliti lain membahas mengenai pelaksanaan eksekusi atas jaminan yang dibebani hak tanggungan (Walidani \& Adjie, 2018) (Saputera, Hasan, Sitompul, \& Muliadi, 2015) (Saputera et al., 2015) (Musjtari, Riyanto, \& Setyowati, 2018). Hal ini menunjukkan bahwa permasalahan pinjaman kredit selalu menjadi perbincangan hangat. Sayangnya, kebanyakan peneliti fokus kepada perlindungan kreditor bahkan eksekusi hak tanggungan dan mengabaikan debitor yang lebih membutuhkan perlindungan sehingga perlindungan hukum terhadap debitor dalam pinjaman kredit ini sangatlah penting untuk dikaji lebih komprehensif baik dari segi praktek maupun hukumnya. Tujuan penelitian ini untuk mengungkap fakta di lapangan mengenai perlindungan hukum debitor pada pinjaman kredit dalam meningkatkan taraf hidup dan untuk menganalisis perlindungan hukum debitor pada pinjaman kredit dalam meningkatkan taraf hidup.

\section{B. Metode Penelitian}

Metode penelitian yang digunakan peneliti adalah socio-legal research. Objek penelitiannya adalah hukum, tapi hukum ditempatkan sebagai gejala sosial. Metode pendekatannya adalah kualitatif. Data yang digunakan adalah data sekunder yang diperoleh melalui studi dokumentasi serta data primer yang diperoleh melalui observasi dan wawancara.

Dalam penelitian ini, peneliti mengambil data dari Direktori Putusan Pengadilan Negeri Semarang; Kantor Pelayanan Kekayaan Negara dan Lelang (KPKNL) Kota Semarang; dan Anwar, Agoeng \& Associates. Peneliti melakukan wawancara kepada kepada KPKNL Semarang dan debitor serta melakukan observasi diam-diam terhadap kasus. Selanjutnya, data dianalisis secara kualitatif.

\section{Hasil dan Pembahasan
1. Praktek Perlindungan Hukum Debitor dalam Pinjaman Kredit

Alasan peminjaman uang kepada perbankan tentunya bervariasi, namun yang paling umum adalah untuk tambahan modal bisnis yang kemudian dilakukan perjanjian berupa perjanjian kredit modal. Perjanjian kredit tersebut berbentuk perjanjian baku mengingat klausul-klausulnya telah disediakan kreditor dan tinggal disetujui atau tidak oleh debitor. Terlepas dari bagaimana perjanjian kredit dilakukan, yang harus mendapatkan perhatian lebih adalah tidak selalu usaha seseorang berjalan mulus sehingga sangat memungkinan adanya kredit bermasalah. Mirisnya, meskipun riwayat pembayaran debitor sebelumnya baik, ketika debitor tidak mampu membayar angsuran sebuah keniscayaan agunan yang dijaminkan dalam perjanjian kreditnya dilakukan eksekusi.

Secara yuridis, ketika debitor wanprestasi terhadap perjanjian kredit maka kreditor dapat melakukan eksekusi terhadap agunan yang dijaminkan dengan cara penjualan agunan sebagaimana Pasal 20 Undang-Undang Republik Indonesia Nomor 4 Tahun 1996 tentang Hak Tanggungan Atas Tanah Beserta Benda-Benda yang Berkaitan dengan Tanah (selanjutnya disingkat UU HT), yaitu: Pertama, hak pemegang hak tanggungan pertama untuk menjual objek hak tanggungan sebagaimana dalam Pasal 6. Kedua, title eksekutorial yang terdapat dalam sertifikat hak tanggungan sebagaimana dalam Pasal 14 ayat (2). Ketiga, atas kesepakatan pemberi dan pemegang hak tanggungan penjualannya dapat dilaksanakan di bawah tangan jika dengan demikian akan dapat diperoleh harga tertinggi yang menguntungkan semua pihak. 
Tabel 1.

Data Pelelangan Kota Semarang Tahun 2017-2020

\begin{tabular}{lcccc}
\hline Dasar Pelelangan & $\mathbf{2 0 1 7}$ & $\mathbf{2 0 1 8}$ & $\mathbf{2 0 1 9}$ & per Maret 2020 \\
\hline Pengadilan & 29 & 32 & 27 & 3 \\
Pajak & 11 & 19 & 16 & 1 \\
Pailit & 10 & 11 & 51 & 7 \\
Pasal 6 UU HT & 1.919 & 1.540 & 2.078 & 60 \\
PUPN & - & - & 9 & - \\
\hline
\end{tabular}

Diperoleh peneliti dari KPKNL Semarang

Tabel 2.

Jumlah Data Gugatan kepada KPKNL Kota Semarang Tahun 2017-2020

\begin{tabular}{cc}
\hline Tahun & Jumlah \\
\hline 2017 & 94 \\
2018 & 110 \\
2019 & 153 \\
per Maret 2020 & 22 \\
\hline
\end{tabular}

Diperoleh peneliti dari KPKNL Semarang

Berdasarkan Tabel 1. Data Pelelangan Kota Semarang Tahun 2017, 2018, 2019, dan per Maret 2020 diketahui bahwa jumlah pelelangan terbesar dilakukan dengan dasar Pasal 6 UU HT sebagai primadona. Selain itu, jumlah pelelangan dengan dasar Pasal 6 UU HT cenderung naik setiap tahunnya. Hal ini menurut Dany Kuryanto, bahwa kegiatan ekonomi masyarakat naik dan mendukung pertumbuhan ekonomi (Kuryanto, 2020). Namun, menurut hemat peneliti, adanya kenaikan jumlah pelelangan dengan dasar Pasal 6 UU HT justru menunjukkan bahwa banyak masyarakat yang telah kehilangan tempat tinggal yang merupakan hak dasar setiap warga masyarakat yang dijamin konstitusi. Jadi, hak jual melalui pelelangan ini berdampak signifikan pada penurunan taraf hidup masyarakat (debitor).

Menurut Dany Kuryanto, penjualan melalui eksekusi tentu ditolak dan tidak dikehendaki debitor. Walaupun ada juga yang baru-baru ini menerima penjualan dengan alasan usia sudah tua dan tidak mau memiliki utang sebelum meninggal (Kuryanto, 2020). Hal tersebut tentu satu banding total kasus penjualan agunan melalui lelang. Timbul pertanyaan apa sebenarnya tujuan pemberian kredit. Apakah bank memberikan kredit untuk menjual agunan?

Fakta di lapangan menunjukkan bahwa pelelangan atas agunan yang dibebani hak tanggungan akibat debitor wanprestasi terhadap perjanjian kredit seringkali mendapatkan penolakan yang dapat dilihat dari jumlah gugatan yang masuk ke KPKNL Kota Semarang di Tabel 2.

Berdasarkan Tabel 2. Jumlah Data Gugatan kepada KPKNL Kota Semarang Tahun 2017, 2018, 2019, dan per Maret 2020 maka diketahui bahwa jumlah gugatan kepada KPKNL Kota Semarang cenderung meningkat setiap tahunnya. Hal ini mengindikasikan bahwa banyak masyarakat yang mengeluh dan tidak sepakat tanahnya dijual. Apakah penjualan tersebut memenuhi rasa keadilan dan mampu meningkatkan taraf hidup masyarakat (debitor)? Bukankah hukum untuk mensejahterakan masyarakat? Sebenarnya siapa yang diuntungkan dengan aturan hak menjual berdasarkan UU HT? Apakah masyarakat atau justru perbankan selaku kreditor?

Berikut beberapa putusan-putusan Pengadilan Negeri Semarang berkaitan dengan agunan yang dibebani hak tanggungan yang disengketakan dan dibawa ke pengadilan: 
Tabel 3.

Daftar Putusan Pengadilan Negeri Semarang Berkaitan Pinjaman Kredit

\begin{tabular}{|c|c|c|c|}
\hline NO & PUTUSAN & AMMAR & KETERANGAN \\
\hline 1 & $\begin{array}{l}\text { 560/Pdt.G/ } \\
\text { 2018/PN Smg }\end{array}$ & $\begin{array}{l}\text { Menolak gugatan } \\
\text { Penggugat (debitor) } \\
\text { seluruhnya }\end{array}$ & $\begin{array}{l}\text { Penggugat mengajukan gugatan PMH kepada Tergugat (kreditor } \\
\text { sebagai T1 dan KPKNL Semarang sebagai T2) karena debitor } \\
\text { menganggap proses lelang dan penentuan limit yang jauh dari nilai } \\
\text { yang seharusnya padahal riwayat pembayaran sebelum perpanjangan } \\
\text { kredit tidak bermasalah. }\end{array}$ \\
\hline 2 & $\begin{array}{l}\text { 519/Pdt.G/ } \\
\text { 2018/PN Smg }\end{array}$ & $\begin{array}{l}\text { Gugatan Para } \\
\text { Penggugat (debitor } \\
(\mathrm{P} 1) \text { dan istri debitor } \\
(\mathrm{P} 2) \text { ) tidak dapat } \\
\text { diterima }\end{array}$ & $\begin{array}{l}\text { Penggugat mengajukan gugatan PMH kepada Tergugat (kreditor } \\
\text { sebagai T1 dan KPKNL Semarang sebagai T2) karena T1 tidak } \\
\text { memberikan salinan perjanjian kredit dan tidak sesuai dengan SPFK, } \\
\text { dan ada penurunan pendapatan sehingga pembayaran terganggu tapi } \\
\text { masih memiliki keinginan melunasi tapi yang disesalkan T1 selalu } \\
\text { menakut-nakuti dan mengancam melelang agunan serta } \mathrm{T} 2 \text { tidak } \\
\text { transparansi, tidak memperhatikan nilai keadilan bagi debitur } \\
\text { melainkan hanya nilai utang. }\end{array}$ \\
\hline 3 & $\begin{array}{l}\text { 517/Pdt.G/ } \\
\text { 2018/PN Smg }\end{array}$ & $\begin{array}{l}\text { Menolak gugatan } \\
\text { Penggugat (debitor) } \\
\text { seluruhnya }\end{array}$ & $\begin{array}{l}\text { Penggugat mengajukan gugatan PMH kepada Tergugat (kreditor) } \\
\text { karena telah memasang MMT yang berisikan tanah diagunkan dan } \\
\text { akan dilaksanakan lelang dan nilai limit yang rendah. Padahal } \\
\text { penggugat berdasarkan riwayat peminjaman telah mengangsur } \\
\text { lancar selama lebih dari } 4 \text { tahun bahkan karena top score maka } \\
\text { ditambahi kreditnya oleh kreditor, cicilan lancar sampai kurang lebih } \\
\text { tiga tahun kemudian karena penghasilan menurun maka hanya } \\
\text { menyicil satu juta per bulan dan karena mendapat teguran debitor } \\
\text { mencicilan dua juta perbulan selanjutnya terjadi pemasangan MMT. } \\
\text { Tergugat malu dan meminta untuk tidak dilakukan penempelan, } \\
\text { namun Tergugat meminta Penggugat membuat surat pernyataan } \\
\text { untuk membayar cicilan dua puluh juta pada bulan tersebut dan lima } \\
\text { puluh juta pada bulan berikutnya kemudian karena Penggugat tidak } \\
\text { mampu maka dilakukan pemasangan MMT kembali. }\end{array}$ \\
\hline 4 & $\begin{array}{l}\text { 182/Pdt.G/ } \\
\text { 2018/PN Smg }\end{array}$ & $\begin{array}{lr}\text { Menolak } & \text { gugatan } \\
\text { Para } & \text { Pelawan } \\
\text { (debitor) } & \text { untuk } \\
\text { seluruhnya } & \end{array}$ & $\begin{array}{l}\text { Para Pelawan mengajukan gugatan perlawan karena permohonan } \\
\text { restrukturisasi ditolak Terlawan } 1 \text { (kreditor) padahal masih memiliki } \\
\text { kemampuan membayar dan tidak dipedulikan hak nasabah dan nasib } \\
\text { karyawannya. Para Terlawan tidak memiliki itikad buruk dan } \\
\text { memang dalam kondisi kehilangan omset cukup signifikan. Para } \\
\text { Perlawan beritikad baik untuk memenuhi kewajiban dengan } \\
\text { kemampuan bayar yang masih dimiliki, namun permohonan } \\
\text { restrukturisasi Pelawan } 1 \text { ditolak Terlawan 1. Para Pelawan sudah } \\
\text { berusaha mencicil kewajiban tapi ditolak Terlawan 1. Ada } \\
\text { pernyataan pembeli lelang sudah berpengalaman maka kemungkinan } \\
\text { akan membeli jaminan jauh di bawah harga pasarnya. }\end{array}$ \\
\hline 5 & $\begin{array}{l}\text { 86/Pdt.G/ } \\
\text { 2019/PN Smg }\end{array}$ & $\begin{array}{l}\text { Gugatan perlawanan } \\
\text { Pelawan (debitor) } \\
\text { tidak dapat diterima }\end{array}$ & $\begin{array}{l}\text { Pelawan mengajukan gugatan perlawanan atas lelang karena } \\
\text { Terlawan } 1 \text { (kreditor) sangat arogansi dan serta merta menyerahkan } \\
\text { kepada Terlawan II (KPKNL) untuk melakukan penjualan melalui } \\
\text { lelang tanpa pemberitahuan. }\end{array}$ \\
\hline 6 & $\begin{array}{l}\text { 300/Pdt.G/ } \\
\text { 2019/PN Smg } \\
\text { dan 299/Pdt.G/ } \\
\text { 2019/PN Smg }\end{array}$ & $\begin{array}{l}\text { Menolak gugatan } \\
\text { Penggugat (debitor) } \\
\text { untuk seluruhnya }\end{array}$ & $\begin{array}{l}\text { Penggugat mengajukan gugatan } \mathrm{PMH} \text { karena agunan dijual dengan } \\
\text { harga sangat murah dan rekayasa pelaksanaan lelang agar } \\
\text { pemilik/pengurus dari debitor dapat menguasai agunan. }\end{array}$ \\
\hline 7 & $\begin{array}{l}\text { 589/Pdt.G/ } \\
\text { 2018/PN Smg }\end{array}$ & $\begin{array}{l}\text { Menolak gugatan } \\
\text { Penggugat (debitor) } \\
\text { untuk seluruhnya }\end{array}$ & $\begin{array}{l}\text { Penggugat mengajukan PHM karena Tergugat } 1 \text { (kreditor) tidak } \\
\text { memberikan akad kredit dan SHT, tidak bersedia membuka mediasi } \\
\text { nonlitigasi, melalaikan peringatan tergugat mengenai hasil karya, } \\
\text { hak cipta, hak kekayaan intelektual, badan usaha, merk, publikasi, } \\
\text { alat peraga, prestasi, dan potensi yang bertumbuh dan menjadi } \\
\text { kesatuan tanah di atasnya, melakukan lelang tanpa fiat pengadilan, } \\
\text { melakukan lelang empat kali tanpa menimbang peringatan, harga } \\
\text { nilai limit rendah, jauh dari harga pasar dan tidak wajar. }\end{array}$ \\
\hline
\end{tabular}

Diperoleh dari Direktori Putusan Pengadilan Negeri Semarang 
Banyaknya sengketa tersebut semakin mendukung pernyataan bahwa mayoritas masyarakat tidak sepakat dengan adanya penjualan agunan tersebut dan tidak sesuai dengan rasa keadilan masyarakat. Berdasarkan ringkasan perkara dapat diketahui faktor kredit bermasalah yang utama adalah penurunan pendapatan dari kegiatan bisnisnya. Pengajuan gugatan umumnya dengan gugatan perbuatan melawan hukum dan perlawanan atas lelang. Dan alasan-alasan penolakan penjualan agunan menurut debitor, yaitu nilai limit terlalu rendah, penolakan negosiasi/ restrukturisasi/ mediasi, tidak mempertimbangkan riwayat debitor dan kondisi debitor, debitor masih memiliki kemampuan membayar kewajiban, tidak diserahkannya perjanjian kredit maupun SHT, mafia lelang, dan arogansi debitor menjual agunan bahkan memilikinya dengan cara tidak patut. Hal ini semakin mendorong pernyataan bahwa penjualan agunan ini mengusik rasa keadilan masyarakat yang berimplikasi pada penurunan taraf hidup masyarakat.

\section{Perlindungan Hukum Debitor untuk Meningkatkan Taraf Hidup}

Perlindungan hukum debitor selaku konsumen sektor jasa keuangan dapat dilihat dalam Peraturan Otoritas Jasa Keuangan Nomor 1/POJK.07/2013 tentang Perlindungan Konsumen Sektor Jasa Keuangan (selanjutnya disingkat POJK 1/2013) dimana dalam perlindungannya menerapkan prinsip: a). transparansi; b). perlakuan yang adil; c). keandalan; d). kerahasiaan dan keamanan data/informasi Konsumen; dan e). penanganan pengaduan serta penyelesaian sengketa konsumen secara sederhana, cepat, dan biaya terjangkau. Sayangnya meskipun telah diatur in casu Pasal 11 ayat (1) bahwa sebelum konsumen menandatangani perjanjian, pelaku usaha jasa keuangan wajib menyampaikan dokumen yang berisi syarat dan ketentuannya, hal ini tidak dapat menunjukkan adanya perlindungan hukum terhadap debitor mengingat bentuk perjanjian kredit adalah perjanjian baku. Jadi, meskipun ada aturan mengenai perlindungan hukum terhadap debitor dalam pinjaman kredit, perlindungan hukum tersebut tidak dapat terwujud mengingat bentuk perjanjian kredit antara debitor dan kreditor adalah perjanjian baku.

Dalam perjanjian baku, debitor hanya memiliki pilihan antara menerima atau menolak (take it or leave it). Perjanjian baku merupakan perjanjian yang hampir seluruh klausulnya sudah dibakukan oleh pemakainya dan pihak lain pada dasarnya tidak mempunyai peluang untuk merundingkan atau meminta perubahan (Sjahdeini, 1993). Jadi, sejak dibuatnya perjanjian, telah terlihat adanya bargaining power yang tidak seimbang. Padahal dalam kebebasan berkontrak, apabila kedudukan para pihak tidak berada dalam bargaining power yang seimbang dapat mendatangkan ketidakadilan. Bargaining power yang tidak seimbang terjadi apabila pihak yang kuat dapat memaksakan kehendaknya kepada pihak yang lemah, hingga pihak yang lemah mengikuti saja syarat-syarat kontrak yang diajukan kepadanya. Pada waktu pinjaman kredit akan diberikan, memang bank dalam posisi yang lebih kuat karena pada saat pembuatan perjanjian itu calon nasabah debitor sangat membutuhkan bantuan kredit. Pada umumnya, calon debitor tidak akan banyak menuntut karena khawatir pemberian kredit tersebut akan dibatalkan. Hal tersebut menyebabkan posisi tawarmenawar bank menjadi sangat kuat. Bagi para pengusaha menengah dan golongan ekonomi lemah, kredit mempunyai kedudukan yang bersifat seller's market. Hal ini secara tidak langsung telah menyimpangi Pasal 17 POJK 1/2013 bahwa pelaku usaha jasa keuangan dilarang menggunakan strategi pemasaran produk dan/atau layanan yang merugikan konsumen dengan memanfaatkan kondisi konsumen yang tidak memiliki pilihan lain dalam mengambil keputusan. Namun, bagi pengusaha konglomerat, posisi bank justru berada dalam kedudukan yang lemah karena jumlahnya tidak banyak sering menjadi 
objek persaingan antarbank. Pengusaha konglomerat dengan mudah berpindah bank apabila merasa tidak puas dengan banknya semua, sehingga agar tidak kehilangan nasabah golongan ini yang besar sumbangannya terhadap profitabilitas bank maka bank sering bersikap mengalah terhadap tuntutan-tuntutan atau persyaratanpersyaratan yang diminta oleh mereka (Sjahdeini, 1993).

Oleh karenanya, dalam mengadakan perjanjian kredit, perlu adanya pembatasan, yaitu: Pertama, Pancasila sebagai sumber segala sumber hukum. Menurut Philipus M. Hadjon, Pancasila pada akhirnya mengarah kepada usaha tercapainya keserasian dan keseimbangan dalam hidup dan kehidupan (Hadjon, 1987). Pancasila yang terkandung di dalamnya gotong-royong dan menjiwai sistem ekonomi bangsa Indonesia, sebagai dasar negara menganut asas keselarasan dan keseimbangan baik dalam hidup manusia sebagai pribadi dan dalam hubungan manusia dengan masyarakat. Dengan sila kedua, manusia diakui dan diperlakukan sesuai dengan harkat dan martabatnya sebagai makhluk Tuhan YME. Dalam pidato lahirnya Pancasila tanggal 1 Juni 1945, Ir. Soekarno mengatakan bahwa kalau kita mencari demokrasi, hendaknya bukan demokrasi Barat, tetapi permusyawaratan yang memberi hidup, yaitu demokrasi politik-ekonomi yang mampu mendatangkan kesejahteraan sosial. Jadi, Pancasila tidak menghendaki adanya perjanjian yang berat sebelah yaitu yang isinya menindas hak-hak salah satu pihak. Menurut Soeharto sehubungan dengan sila kedua bahwa pandangan bangsa Indonesia terhadap manusia tidak menghendaki adanya penindasan manusia oleh manusia lain, baik secara lahiriah maupun secara bathiniah. Kita tidak boleh memberi tempat kepada usaha yang bertujuan merusak dengan berlindung di balik tirai kebebasan azasi. Selain itu, perjanjian yang tidak seimbang ini juga bertentangan dengan sila kelima. Soeharto mengemukakan bahwa keadilan sosial berarti harus melindungi yang lemah. Perlindungan yang diberikan adalah untuk mencegah kesewenang-wenangan dari yang kuat untuk menjamin adanya keadilan. Kebebasan yang tidak berbatas bertentangan dengan asas keselarasan dan keseimbangan menurut Pancasila (Sjahdeini, 1993).

Kedua, KUHPer dimana ada tiga pasal sebagai tolok ukur dalam perjanjian, yaitu: Pertama, Pasal 1337, berbunyi "Suatu kausa adalah terlarang, apabila kausa itu dilarang oleh undang-undang, atau bertentangan dengan kesusilaan yang baik (moral) atau dengan ketertiban umum." Jadi, dalam mengadakan perjanjian kredit, isi dan materi muatannya tidak boleh bertentangan dengan undang-undang, moral, dan ketertiban umum. Kedua, Pasal 1338 ayat (3), berbunyi "Suatu perjanjian harus dilaksanakan dengan itikad baik." Dengan demikian, asas ini mengandung pengertian para pihak tidak dapat sekehendaknya tetapi dibatasi oleh itikad baik yang di dalamnya juga mengandung keadilan. Perjanjian harus dilakukan dengan itikad baik, yaitu sejak memasuki perjanjian dan bekerja setelah perjanjian dibuat. Oleh karenanya pembuatan perjanjian harus dilandasi asas kemitraan. Landasan asas kemitraan adalah asas itikad baik dan sesungguhnya nasabah merupakan mitra usaha bank. Nasabah tidak dapat berkembang usahanya tanpa bank dan sebaliknya bank juga tidak dapat berkembang usahanya tanpa nasabah sehingga harus saling menjadi mitra, maka dalam perjanjian di antara mereka tidak boleh ada yang lebih kuat kedudukannya (Sjahdeini, 1993). Menurut Subekti, hukum selalu mengejar dua tujuan, yaitu menjamin kepastian (ketertiban) dan memenuhi tuntutan keadilan. Kepastian hukum menghendaki supaya apa yang dijanjikan harus dipenuhi (ditepati), namun dalam menuntut dipenuhinya janji itu, janganlah orang meninggalkan norma-norma keadilan atau kepatutan. Berlakulah adil dalam menuntut pemenuhan janji itu! (Sjahdeini, 1993) Ketiga, Pasal 1339, "Persetujuanpersetujuan tidak hanya mengikat untuk halhal yang dengan tegas dinyatakan di dalamnya, tetapi juga untuk segala sesuatu yang menurut sifat dari persetujuan itu 
diharuskan oleh kepatutan, kebiasaan atau undang-undang." Jadi, dalam mengadakan perjanjian kredit, persetujuan tersebut tidak hanya mengikat apa yang tertuang dalam isi perjanjian, melainkan juga kepatutan, kebiasaan, dan undang-undang. Menurut Herlien Budiono, kebebasan berkontrak dalam hal ini terhadap isi atau cakupan materinya, namun muatan isi hubungan kontraktrual ditentukan kepatutan dan kelayakan (redelijkheid en bijlijkheid), kesusilaan yang baik (goede zeden), dan ketertiban umum (openbare orde) (Budiono, 2015).

Perlindungan hukum debitor dengan adanya perjanjian baku telah bertentangan dengan tolok ukur tersebut. Belum lagi apabila timbul kredit bermasalah, agunan yang dibebani hak tanggungan dapat dieksekusi oleh kreditor sebagaimana pembahasan sebelumnya mengenai maraknya eksekusi hak tanggungan berdasarkan Pasal 6 UU HT. Eksekusi hak tanggungan berdasarkan Pasal 20 jo. Pasal 6 UU HT menurut hemat peneliti adalah rancu. Disebutkan in casu Pasal 6, bahwa apabila debitor cidera janji, pemegang hak tanggungan pertama mempunyai hak untuk menjual objek hak tanggungan atas kekuasaan sendiri melalui pelelangan umum serta mengambil pelunasan piutangnya dari hasil penjualan tersebut. Kemudian dijelaskan lebih lanjut, Penjelasan Pasal 6, bahwa hak untuk menjual objek hak tanggungan atas kekuasaan sendiri merupakan salah satu perwujudan dari kedudukan diutamakan yang dipunyai oleh pemegang hak tanggungan atau pemegang hak tanggungan pertama dalam hal terdapat lebih dari satu pemegang hak tanggungan. Apabila dilihat dari klausul Penjelasan Pasal 6 maka ia mengadopsi Pasal 1178 KUHPer dimana diperkenankan pemegang hipotik pertama pada waktu membuat hipotik dengan tegas meminta diperjanjikan jika utang tidak dilunasi untuk mengambil pelunasan utang dari penjualan melalui lelang. Menjual sendiri dengan kewenangannya disini lazim disebut parate executie yang pelaksanaannya tunduk kepada Pasal 224 HIR dan Pasal 258 RBg dimana apabila tidak diperjanjikan kuasa menjual sendiri, penjualan lelang (executoriale verkoop) harus diminta kepada ketua pengadilan negeri dan permintaan tersebut berdasarkan alasan cidera janji. Selain itu, pelaksanaan parate executie jika mengacu pada Putusan Mahkamah Agung Nomor 3210 K/Pdt/1984 tanggal 30 Januari 1986 maka lelang umum yang dilaksanakan sendiri oleh kantor lelang negara atas perintah bank (kreditor) dan tidak atas fiat pengadilan negeri bertentangan dengan Pasal 224 HIR, sehingga pelelangan tersebut tidak sah. Jadi, menurut putusan ini pelaksanaan parate executie harus dengan fiat pengadilan negeri. Hal ini juga didukung oleh Buku II Pedoman Mahkamah Agung Republik Indonesia yang mengharuskan adanya fiat eksekusi dari pengadilan negeri (Tanuwidjaja, 2016). Jadi, antara Pasal 6 dan Penjelasan Pasal 6 menunjukkan perbedaan yang mendasar. Apabila mengacu Penjelasan Pasal 6 maka seyogyanya proses eksekusi tetap melalui fiat pengadilan, namun faktanya pelaksanaan Pasal 6 UU HT ini terkesan mudah cukup melalui KPKNL seperti pembahasan sebelumnya. Adanya ketentuan ini sangat melemahkan perlindungan hukum debitor dan berorientasi pada kepentingan kreditor semata. Pasal 6 ini juga menyebutkan bahwa hak untuk menjual objek hak tanggungan atas kekuasaan sendiri merupakan salah satu perwujudan dari kedudukan diutamakan. Sementara, hak untuk menjual objek hak tanggungan atas kekuasaan sendiri adalah bukan perwujudan kedudukan diutamakan, tetapi sebagai perwujuan prinsip mempercepat pelunasan piutang kreditor. Kedudukan kreditor preferen menunjukkan bahwa pemenuhan prestasinya lebih didahulukan dari piutang yang lain yang timbul dari perjanjian jaminan khusus. Dengan demikian, eksekusi tersebut menunjukkan perlindungan debitor semakin rentan dan lebih berpihak kepada kepentingan kreditor sehingga lumrah apabila menjadi primadona dalam penjualan agunan. Berdasarkan alasan mudahnya 
dalam penjualan agunan, adanya alternatif pilihan cara penjualan yang terdiri dari tiga macam eksekusi, dan kontroversi rumusan pasalnya menunjukkan UU HT ini tidak benar karena isinya menjual tanah.

Padahal kredit bermasalah tidak serta merta karena kesalahan debitor sebagai faktor internal, melainkan juga kreditor dan belum lagi ada faktor eksternal. Menurut Veithrizal Rivai, et. al. Penyebab timbulnya kredit bermasalah, yaitu: Pertama, karena kesalahan bank, di antaranya kurang pengecekan terhadap latar belakang calon nasabah; kurang tajam dalam menganalisis terhadap maksud dan tujuan penggunaan kredit dan sumber pembayaran kembali; kurang pemahaman terhadap keuntungan keuangan yang sebenarnya dari calon nasabah dan apa manfaat kredit yang diberikan; kurang mahir dalam menganalisis laporan keuangan calon nasabah; kurang lengkap mencantumkan syarat-syarat; terlalu agresif; pemberian kelonggaran terlalu banyak; kurang pengalaman dari account officer; account officer mudah dipengaruhi, diintimidasi, atau dipaksa oleh calon nasabah; kurang berfungsinya credit recovery officer, keyakinan yang berlebihan; kurang mengadakan review, minta laporan, dan menganalisis laporan keuangan serta informasi-informasi kredit lainnya; kurang mengadakan kunjungan on the spot pada lokasi perusahaan nasabah; kurang mengadakan kontak dengan nasabah; pemberian kredit terlalu banyak tanpa didasari campur tangan yang berlebihan dari pemilik; dan sebagainya. Kedua, karena kesalahan nasabah, di antaranya nasabah tidak kompeten nasabah tidak atau kurang pengalaman; nasabah kurang memberikan waktu untuk usahanya; nasabah tidak jujur; nasabah serakah. Ketiga, faktor eksternal, yaitu akibat perubahan pada external environment seperti perubahan-perubahan political dan legal environment, deregulasi sektor real, financial dan economic menimbulkan pengaruh yang merugikan bagi debitor, misalnya kondisi perekonomian, perubahan-perubahan peraturan; dan bencana alam (Rivai,
Veithzal, \& Idroes, 2007). Jadi, kredit bermasalah tidak serta merta hanya disebabkan oleh debitor.

Menurut Pasal 8 UU Perbankan maka dalam memberikan kredit bank wajib mempunyai keyakinan atas kemampuan dan kesanggupan debitor untuk melunasinya yang dalam hal ini Widjanarko mengatakan sebelum memberikan kredit bank wajib melaksanakan penilaian yang seksama terhadap watak, kemampuan, modal, aguanan dan prospek usaha dari nasabah debitor (Widjanarto, 2003). Kreditor harus menganalisis dari segi legal (misalnya apakah benar atas nama debitor; apakah jaminan berupa tanah dapat dibebani hak tanggungan mengingat tidak semua tanah dapat dibebani hak tanggungan, melainkan hanya tanah dengan status hak milik, hak guna usaha, hak guna bangunan, hak pakai, dan hak atas tanah berikut bangunan, tanaman, dan hasil karya yang telah ada atau akan ada yang merupakan satu kesatuan dengan tanah merupakan hak milik pemegang hak atas tanah); sosial (misalnya bagaimana struktur sosialnya; apakah dari pengusaha/ bukan, dan kalaupun direktur apakah satu hari baru menjadi direktur atau sudah berpengalaman dan berapa tahun); ekonomi (misalnya mengakunya pengusaha tapi ternyata dilihat dari rumahnya tidak memungkinkan). Faktanya, banyak terjadi kesalahan menganalisis dalam pemberian kredit kepada calon debitor bahkan manipulasi harga sehingga terjadi mark up nilai agunan.

Selain itu, pada dasarnya kreditor telah mendapatkan keuntungan yang sudah lebih dari cukup. Apalagi dewasa ini, perbankan kerap memberikan kredit dengan suku bunga flat (pembayaran kredit flat) yang keuntungannya jauh lebih banyak di banding suku bunga menurun (pembayaran kredit efektif) maka seharusnya dapat memberikan toleransi kepada debitor karena bank sudah mendapatkan keuntungan berlipat-lipat. Kredit bermasalah merupakan risiko bank selaku kreditor. Masalah suku bunga juga pernah diekspos dalam media cetak, misalnya berita pergerakan rentang atau 
spread suku bunga perbankan di Indonesia tergolong anomali dibandingkan dengan negara tetangga. Di tengah perlambatan ekonomi, laba bersih perbankan nasional justru mencetak rekor mencapai $\mathrm{Rp}$ 41,39 triliun per November 2009 (Kompas, 2010) dan berita margin profit perbankan di Indonesia tahun 2009 merupakan salah satu yang tertinggi di dunia sehingga harus bunga kredit harus ditekan sehingga tidak terlalu memberatkan dunia usaha. Tingginya margin profit ini menjadi salah satu alasan investor asing marak menanamkan investasinya di sektor perbankan nasional. Kondisi ini yang membuat perbankan tetap menikmati laba yang besar meskipun penyaluran kreditnya anjlok. Menurut Drajad Wibowo, margit profit yang tinggi dipakai perbankan untuk bantalan (buffer) terhadap risiko mengingat bank terlibat transaksi investasi keuangan yang berisiko tinggi. Kalau produk investasi ini untung, bank akan berlipat profitnya. Tapi, kalau produk investasi itu rugi, bank mempunyai buffer (Kompas, 2009). Belum lagi ada resesi ekonomi dimana pemberian kredit sekarang belum tentu nilainya masih sama sepuluh bulan ke depan karena kurs rendah. Untuk waktu ke depan belum tentu dapat sama maka bank sebenarnya sudah mendapatkan keuntungan.

Menurut hemat peneliti, ada beberapa hal yang penting untuk disoroti, yaitu: Pertama, ketentuan pinjaman kredit dan UU HT khususnya mengenai penjualan agunan seyogyanya sesuai dengan semangat filosofi pembangunan ekonomi. Penyaluran kredit sebagai salah satu wujud usaha pembangunan ekonomi yang merupakan bagian dari pembangunan nasional merupakan salah satu upaya untuk mewujudkan kesejahteraan rakyat yang adil dan makmur berdasarkan Pancasila dan UUD NRI Tahun 1945. Jadi, tujuan akhir dari pembangunan nasional pada dasarnya adalah untuk mewujudkan kesejahteraan masyarakat yang juga sebagai tujuan nasional sebagaimana alinea keempat UUD NRI Tahun 1945 serta merupakan jaminan konstitusi sebagaimana Pasal $28 \mathrm{H}$ dimana ada hak setiap orang untuk hidup sejahtera. Namun, adanya bentuk perjanjian baku dan ketentuan penjualan agunan secara mudah dalam UU HT didukung maraknya praktik penjualan agunan telah mengusik rasa keadilan bagi masyarakat yang pada akhirnya menurunkan taraf hidup masyarakat (debitor). Padahal keadilan merupakan salah satu tujuan nasional juga bahkan dijamin pula dalam konstitusi sebagaimana Pasal 28D dimana setiap orang berhak atas kepastian hukum yang adil. Hak yang adil untuk menebus pada dasarnya adalah hak yang didasarkan pada pertimbangan yang adil bahwa pemberi hak tanggungan adalah pemilik sebenarnya dari properti dan bahwa kreditor hanya memegang hak tanggungan sebagai jaminan karena minatnya terletak pada pembayaran utang. Sebenarnya niat bank itu memberikan kredit dan meminta pelunasan berupa uang atau menjual agunan. Bagaimana mungkin meminjam uang menjadi menjual tempat tinggal. Ada pepatah menyatakan sekali mortgage maka selalu mortgage. Hal ini menjaga pemahaman awal antara para pihak dan memastikan bahwa perjanjian tidak mengandung ketentuan yang dapat memberikan hak untuk menebus ilusi atau yang menyumbat keadilan (Nwagbara, 2014).

Kedua, hak setiap warga negara untuk bertempat tinggal. Menurut Pasal 28H UUD NRI Tahun 1945, bahwa setiap orang berhak hidup sejahtera lahir dan batin, bertempat tinggal, dan mendapatkan lingkungan yang baik dan sehat serta berhak memperoleh pelayanan kesehatan. Jadi, jelas bahwa hak untuk bertempat tinggal dijamin oleh konstitusi dan negara (pemerintah) sebagai pelaksana berkewajiban penuh untuk memberikan dan memastikan setiap warga negara untuk bertempat tinggal. Namun, dengan adanya penjualan agunan ini khususnya kemudahan eksekusi dalam Pasal 6 UU HT memberikan dampak banyaknya masyarakat yang justru kehilangan tempat tinggalnya padahal ini merupakan tanggung jawab negara. 
Ketiga, definisi bank menurut Pasal 1 angka 2 UU Perbankan, yaitu badan usaha yang menghimpun dana dari masyarakat dalam bentuk simpanan dan menyalurkannya kepada masyarakat dalam bentuk kredit dan/atau bentuk-bentuk lainnya dalam rangka meningkatkan taraf hidup rakyat banyak. Bank merupakan badan usaha yang menghimpun dana dari masyarakat dalam bentuk simpanan dan menyalurkannya dalam bentuk kredit, maka bank berperan sebagai intermedier dalam rangka meningkatkan taraf hidup rakyat banyak. Sementara, perlindungan hukum debitor sudah lemah dari sejak awal pembuatan perjanjian kredit sampai dengan penjualan agunan.

Keempat, tujuan perbankan Indonesia adalah menunjang pelaksanaan pembangunan nasional dalam rangka meningkatkan pemerataan, pertumbuhan ekonomi, dan stabilitas nasional ke arah peningkatan kesejahteraan rakyat banyak sebagaimana Pasal 4 UU Perbankan. Jadi, tujuan utama perbankan adalah peningkatan kesejahteraan, prakteknya justru banyak masyarakat yang merasa tidak mendapatkan keadilan dan kehilangan tempat tinggalnya sehingga tujuan tersebut tidak terwujud yang berimplikasi pada tidak tercapai pula peningkatan taraf hidup.

Berdasarkan hal tersebut di atas, pembuatan perjanjian kredit hingga pelaksanaan eksekusi agunan menuai kontroversi dan melemahkan perlindungan hukum pada debitor. Menurut hemat peneliti, beberapa usulan yang tepat agar memberikan perlindungan hukum pada debitor sehingga meningkatkan taraf hidup, sebagai berikut: Pertama, penjualan agunan hanya dengan dua cara saja, yaitu melalui fiat pengadilan dan di bawah tangan berdasarkan kesepakatan debitor dan kreditor apabila dimungkinkan mendapatkan harga tertinggi. Artinya, peneliti lebih sepakat untuk kembali kepada model eksekusi terdahulu berdasarkan KUHPer. Menurut Subekti yang dikutip Herlien Budiono, "janganlah kita membuang hal-hal yang baik, biarpun itu berasal dari penjajah"
(Herlien, hal. 73). Jika memang UU HT sebagai hukum nasional tidak lebih baik dari KUHPer warisan Belanda. Hal ini mengingat UU HT sendiri pada dasarnya mengadopsi KUHPer, namun UU HT ini justru rancu dalam rumusan pasalnya dan mempermudah penjualan agunan sehingga melemahkan perlindungan hukum debitor. Kedua, percontohan model Organisasi Profesi Tani di Jepang. Organisasi ini bertanggung jawab apabila anggotanya tidak melunasi kredit yang didapat. Jadi, organisasi ini berperan sebagai penjamin bagi debitor. Ketiga, kembali kepada Panitia Urusan Piutang Lelang Negara (PUPLN). Jika dilihat secara historis, dahulu ada lembaga PUPLN yang menangani masalah apabila ada debitor yang tidak dapat melunasi kreditnya sehingga ada pergeseran pengurusan masalah dari kreditor ke PUPLN. Berbeda dengan sekarang, kita hanya mengenal panitia lelang melalui KPKNL. Keempat, optimalisasi peran PT Asuransi Kredit Indonesia (Askrindo) dan Jaminan Kredit Indonesia (Jamkrindo). Adapun tujuan asuransi kredit tersebut adalah untuk menutup risiko atas kerugian yang diderita oleh bank sebagai akibat tidak dibayarnya kembali kredit oleh nasabah. Terjadi pengalihan risiko melalui asuransi dan jika masih tidak mampu maka dapat direasuransikan. Bank dalam berhubungan dengan perusahaan asuransi bukan bertindak untuk dirinya sendiri tetapi untuk dan atas nama nasabah debitor. Debitorlah yang membayar premi sehingga seharusnya dapat ditanggung risiko akibat tidak dapat dilunasinya kredit, sementara prakteknya asuransi kredit hanya mau menerima pembayaran preminya saja.

\section{Simpulan dan Saran}

Berdasarkan uraian tersebut di atas, fakta di lapangan menunjukkan bahwa perjanjian kredit merupakan perjanjian baku dan tidak dapat dipungkiri memungkinkan adanya kredit bermasalah. Terjadi peningkatan penjualan agunan untuk pelunasan kredit dengan Pasal 6 UU HT sebagai primadona dasar penjualan agunan 
yang mengindikasikan bahwa semakin meningkat pula masyarakat yang kehilangan tempat tinggal sebagai hak dasarnya. Hal ini telah mengusik rasa keadilan masyarakat dibuktikan dengan banyaknya gugatan yang ditujukan kepada KPKNL maupun dari sengketa-sengketa yang masuk di pengadilan yang berimplikasi pada penurunan taraf hidup masyarakat.

Perlindungan hukum debitor dapat dilihat dalam POJK 1/2013, namun nyatanya perlindungan tersebut tidak dapat terwujud mengingat bentuk perjanjian kredit antara debitor dan kreditor adalah perjanjian baku sehingga terdapat bargaining power yang tidak seimbang dan rentan ketidak-adilan. Perjanjian baku telah bertentangan dengan tolok ukur Pancasila dan KUHPer (Pasal 1337, Pasal 1338 ayat (3), Pasal 1339).

Apabila pinjaman kredit bermasalah (debitor wanprestasi) maka agunan dapat dijual. Penjualan agunan yang mudah bahkan UU HT yang rumusan pasalnya rancu menyebabkan perlindungan hukum debitor terhadap pinjaman kredit sejak awal pembuatan perjanjian sampai dengan penjualan agunan sangatlah lemah sehingga berdampak pada taraf hidup masyarakat. Kesalahan kredit bermasalah pada dasarnya bukan hanya kesalahan debitor. Suku bunga flat yang sering digunakan bank juga telah menghasilkan keuntungan berlipat-lipat ditambah adanya resesi ekonomi sehingga kredit bermasalah adalah risiko kredit.

Ketentuan pinjaman kredit seyogyanya sesuai dengan semangat filosofi pembangunan ekonomi yaitu mewujudkan kesejahteraan dan keadilan. Di samping itu, banyaknya masyarakat yang kehilangan tempat tinggal telah menyimpangi hak untuk bertempat tinggal. Padahal bank merupakan intermedier dalam rangka peningkatan taraf hidup yang selaras dengan tujuannya yaitu peningkatan kesejahteraan. Beberapa usulan yang tepat agar memberikan perlindungan hukum pada debitor sehingga meningkatkan taraf hidup, sebagai berikut: penjualan agunan dilakukan dengan dua cara saja yaitu fiat pengadilan dan di bawah tangan apabila akan diperoleh harga tertinggi; percontohan model Organisasi Profesi Tani di Jepang; kembali kepada PUPLN; dan optimalisasi Askrindo dan Jamkrindo.

\section{DAFTAR PUSTAKA}

Anwar, M. . (2014). Perlindungan Hukum Terhadap Kreditur dalam Perjanjian Kredit dengan Jaminan Hak Tanggungan Menurut Undang-Undang No. 4 Tahun 1996. Jurnal Jendela Hukum Fakultas Hukum UNIJA, I(1).

Aryani, F. K., \& Djajaputra, G. (2018). Perlindungan Hukum bagi Kreditur Pemegang Hak Tanggungan Terhadap Sengketa Agunan yang Mengakibatkan Batalnya Perjanjian Kredit. Jurnal Hukum Adigama, 1(1).

Bahsan, M. (2012). Hukum Jaminan dan Jaminan Kredit Perbankan Indonesia. Jakarta: Rajawali Pers.

Budiono, H. (2015). Asas Keseimbangan bagi Hukum Perjanjian Indonesia. Bandung: PT Citra Aditya Bakti.

Dianawati, C. B., \& Purnawan, A. (2017). Kajian Hukum Jaminan Hak Tanggungan yang Dilelang tanpa Proses Permohonan Lelang Eksekusi ke Ketua Pengadilan Negeri. Jurnal Akta, 4(2), 125-132. Diambil dari http://jurnal.unissula.ac.id/index.php/akt a/article/viewFile/1755/1315

Hadjon, P. M. (1987). Perlindungan Hukum bagi Rakyat di Indonesia. Surabaya: PT Bina Ilmu.

Kompas. (2009, Agustus 24). Margin Profit Terlalu Tinggi.

Kompas. (2010, Januari 14). Rentang Bunga Cenderung Membesar.

Kuryanto, D. (2020). Wawancara. Semarang: Kantor Pelayanan Kekayaan Negara dan Lelang Semarang.

Musjtari, D. N., Riyanto, B., \& Setyowati, R. (2018). Parate Execution in Disputes Settlement of Financing Contract with 
Mortgage Guaranteed on Islamic Banking Practices. IOP Conference Series: Earth and Environmental Science, 175(1). https://doi.org/10.1088/17551315/175/1/012187

Nwagbara, C. (2014). Enforcement of Mortgage Security in Nigeria. Global Journal of Politics and Law Research, 2(2), 52-63.

Prasojo, E. C., \& Anand, G. (2018). Akibat Hukum Kreditor Pemegang Hak Tanggungan Terhadap Objek Hak Tanggungan Yang Dinyatakan Gugur Demi Hukum Berdasarkan Putusan Pengadilan. Jurnal Selat, 5(2), 148160.

Purnamasari, I. D. (2014). Panduan Lengkap Hukum Praktis Populer: Kiatkiat Cerdas, Mudah, dan Bijak Memahami Masalah Hukum Jaminan Perbankan. Bandung: Kaifa.

Rahmawati, P., \& Cahyaningsih, D. T. (2016). Akibat Hukum Perjanjian Kredit dengan Jaminan Benda Tak Bergerak yang Dibuat di Bawah Tangah pada PT. Bank Rakyat Indonesia (Persero) Cabang Tegal Unit Singkil. Privat Law, IV(2), 72-79.

Risa, Y. (2019). Perlindungan Hukum Terhadap Kreditur Atas Wanprestasi Debitur pada Perjanjian Kredit dengan Jaminan Hak Tanggungan. Jurnal Normative, 5(2), 1689-1699. https://doi.org/10.1017/CBO978110741 5324.004

Rivai, V., Veithzal, A. P., \& Idroes, F. N. (2007). Bank and Financial Institution Management. Jakarta: PT RajaGrafindo Persada.
Saputera, J. A., Hasan, D., Sitompul, Z., \& Muliadi, A. (2015). Parate Execution Secured Assets of Bad Credit In Indonesian Banking System. The Southeast Asia Law Journal, 1(1), 1122.

Sjahdeini, S. R. (1993). Kebebasan Berkontrak dan Perlindungan yang Seimbang bagi Para Pihak dalam Perjanjian Kredit Bank di Indonesia. Jakarta: Institut Bankir Indonesia.

Suwandi, D. N. A. P. (2018). Perlindungan Hukum Bagi Bank Pemegang Hak Tanggungan Peringkat Kedua Dalam Eksekusi Objek Hak Tanggungan. Media Iuris, 1(3), 420-438. https://doi.org/10.20473/mi.v1i3.10183

Tanuwidjaja, T. H. (2016). Parate Eksekusi Hak Tanggungan. Refleksi Hukum, 10(1), 99-109.

Walidani, L., \& Adjie, H. (2018). Perlindungan Hukum Kreditur Terhadap Pelaksanaan Eksekusi Hak Tanggungan (Analisis Putusan Mahkamah Agung Republik Indonesia Nomor 2859k/Pdt/2011). Res Judicata, 1(1), 47-56. https://doi.org/10.29406/rj.vli1.1038

Watikno, A. R., \& Imanullah, M. N. (2019). Perlindungan Hukum Terhadap Kreditor Pemegang Jaminan Hak Atas Tanah yang Belum Terdaftar Akibat Debitor Wanprestasi. Jurnal Repertorium, 6(1).

Widjanarto. (2003). Hukum dan Ketentuan Perbankan di Indonesia. Jakarta: Pustaka Utama Grafiti. 